\title{
Teaching English by using E-learning during COVID-19 Pandemic Time
}

\author{
Fathur Rizqy Az \\ Universitas Negeri Padang \\ email: fathurkiii94@gmail.com
}

\begin{abstract}
COVID-19 a public health crisis of worldwide importance was announced by the World Health Organization (WHO) in January 2020 as a new corona virus disease outbreak and was reported as a pandemic in March 2020. Mr. Joko Widodo, has instructed all Indonesian citizens to practice social and physical distance. To reduce the spread of COVID-19, the Indonesian government implemented certain preventive measures. Mr. Nadiem Anwar Makarim, Indonesia's Minister of Education and Culture, has instructed all students, including University students to study from home. A descriptive qualitative research was used to conduct this study. The study's findings show that in the event in the event of a pandemic, the E-learning system is the only possible teaching learning approach. Teachers and students simply connected to the internet from their homes and were connected to an approved E-learning program by the institutions or lecturers. However, there were undeniable challenges in implementing E-learning, such as a lack of internet access or WIFI, learners getting unmotivated and insufficient levels of student engagement. Affective domains appeared to be minimized in E-learning systems due to a lack of actual social and psychological interactions between teacher and students. The interactive teacher-student discussion is not as productive as it would be in a conventional teaching.
\end{abstract}

Keywords: Teaching English, E-learning, Covid-19 Pandemic

\section{Introduction}

On January 30, 2020, WHO categorized this outbreak as a public health emergency of international concern to identify the type of virus that causes the deaths in Wuhan, WHO collected information, provided guidance and managed expert networks. COVID-19 was the name given to the new corona virus disease by the world health organization on February 11, 2020. Many countries including Asian countries such as Singapore, Malaysia and Indonesia, as well as European countries such as England, Spain and Germany, have confirmed that the corona virus has infected their citizens. The United States of America, as a superpower, has also been affected by the outbreak. This corona virus has caused damage on people's lives.

As one of the largest countries in Southeast Asia, Indonesia has felt the effect of the current pandemic. Early in march, when the first COVID-19 cases were reported in Indonesia, the country was in a panic. As a result, the Indonesian government has implemented a number of efforts to reduce the effects, for example. Physical distancing is currently known as social distancing and it includes health and hygiene campaigns (regular hand washing, wearing a face mask when going out), as well as the closure of public areas such as airports, terminals, malls and offices. In the economic sector, shops that did not offer daily necessities were asked to close, while cafes and restaurants were instructed to only provide take away service.

People began working from home (WFH) to avoid crowds and gatherings. Mr. Nadiem Anwar Makarim, Indonesian Education and Culture Minister, has issued Minister circular letter Number 
302/E.E2/KR/2020 in the education sector. Students were encouraged to study from home (SFH), with classes held remotely. The government's efforts to prevent COVID-19 from entering university populations and spreading to local communities culminated in the move from real teaching-learning processes in the classroom to virtual classrooms. Therefore, teachers and lecturers are required to use online/digital platforms, often known as online learning or E-learning, to teach and manage the learning process. The purpose of this study is to look into the use of E-learning in Indonesia during the Covid-19 pandemic. This study used descriptive qualitative research, in which the researcher does not control or change any of the variables, but instead observes and measures the situation and phenomena.

The term "online learning" refers to education that occurs over the internet. It's also known as 'elearning,' among other things. However, online learning is just one sort of 'distance learning,' which is a catch-all word for any learning that takes place outside of a traditional classroom and takes place over a long distance (Stern, 2018). The online learning system is not the same as traditional education. The fundamental difference is that learners and teachers do not meet in person in online learning. The tactics and problems differ as well. Furthermore, online learning necessitates the use of an interactive telecommunication system to link the professor and the students, as well as the numerous resources required inside it. Because online learning is defined as education that takes place through the internet. In this context, both educators and learners must have technical abilities in the digital world in order to educate online. Learners must also be prepared to learn how to use the technology that is used in their institutions. Online learning is not uncommon in the university setting, as this type of learning interaction model is extensively used on numerous campuses.

There are several reasons why E-learning is appropriate to employ, according to Ghirardini (2011) a large amount of content must be supplied to a large number of students; 2) Learners come from different parts of the country; 3) Learners have limited mobility; 4) Learners have limited time to devote to studying on a regular basis; 5) Learners lack strong listening and reading abilities; 6) Students who lack effective speaking skills or who are bashful; 7) Learners have a working knowledge of computers and the Internet; 8) Learners must build consistent background knowledge of the subject; 10) Learners are highly driven to study and value the ability to work at their own pace; 11) content will need to be reused in the future for new groups of learners; 12) Rather than psychomotor capabilities, training tries to improve cognitive abilities. 13) the course is designed to meet long-term rather than short-term training needs; 14) data collection and tracking are required.

Learners must be self-regulatory in their online actions in order to succeed in online learning. They can use the self-regulated to assist them in making decisions about some parts of their education. They have control over the learning process's goal-setting, planning, monitoring, and assessment phases (Vonderwell, 2004). Learners can make better decision if they are aware of the regulations that govern online learning. They may be able to achieve a positive outcome as a result of this predicament. The students are aware of their obligations and how to successfully manage their time. Because the teacher is not physically present in this environment, the learning emphasis is on active learning, and the lerner's readiness is required.

\section{Methods}

This research used a descriptive qualitative design. The data was gathered using phenomenological research. A qualitative way for describing an event, action, or phenomenon is phenomenological study. In order to get insight into this research, a combination of primary research methods (interviews) and secondary research methods (literature research and web sources) were used. The researcher used an interview technique to interview some instructors from various institutions to learn about their reactions to the E-learning system. The interview was broadcast live on social media (WhatsApp group chat). Meanwhile, the researcher conducted a literature study by reading relevant documents such as books and 
ELT journals/articles. Finally, the researcher acquired data from internet sources such as downloading and streaming videos, as well as reading blogs and webpages.

\section{Result and Discussion}

Based on teachers' e-learning experiences, they looked at online ESL teaching from different degrees of agreement. The participating teachers had almost similar experience of e-learning over COVID-19 when all of them were mainly using WhatsApp application for their online teaching. Interestingly, WhatsApp (75\%) became particularly practical and convenient for their online teaching during the closure of schools as they were able to reach their students. Other online applications that they utilised were: Google Classroom (15\%), Zoom (10\%), and Quizzes (25\%). Figure 2 below represented teachers' modes of online applications.

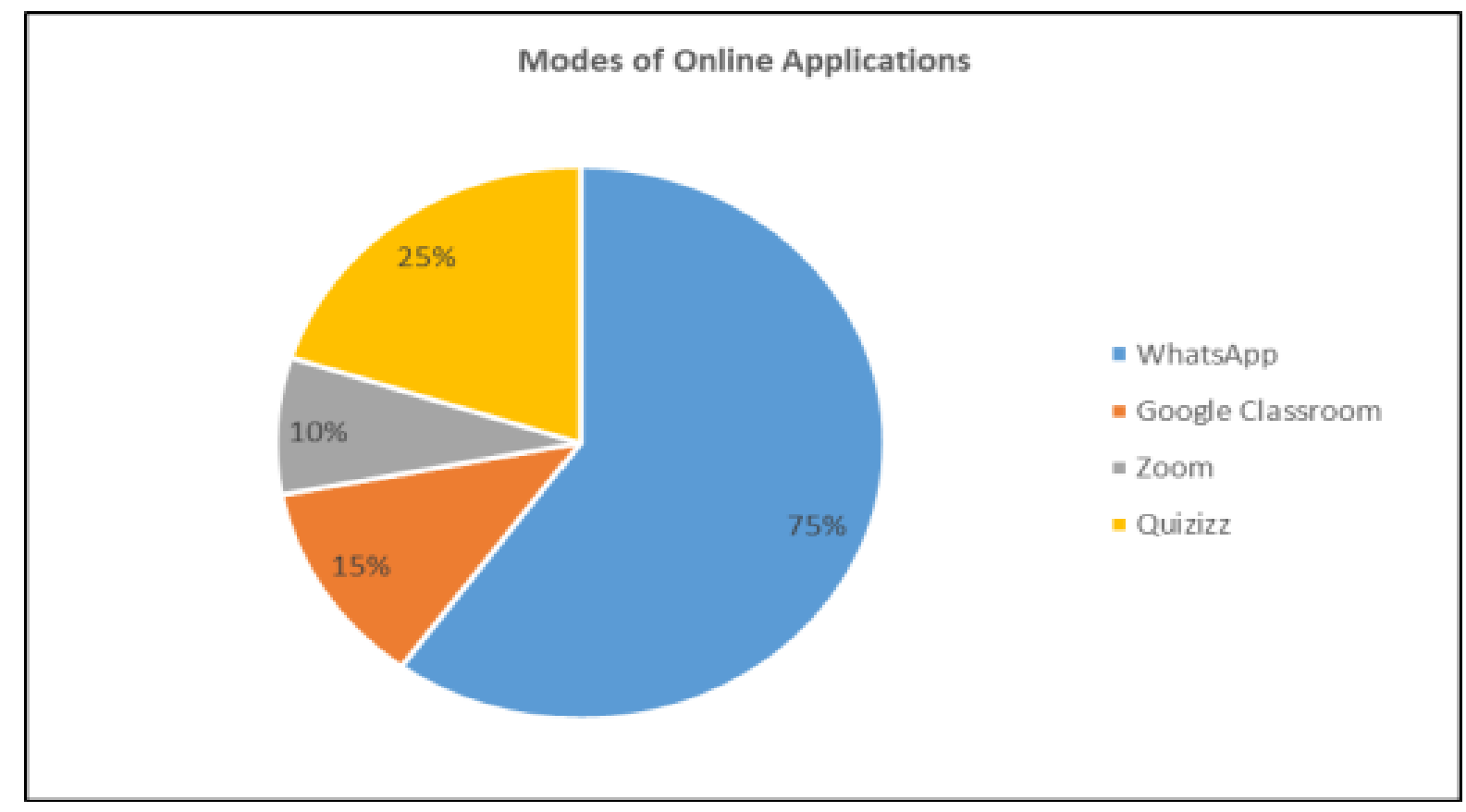

Figure 2: Modes of Online Applications

The following were some excerpts manifested by some interviewees:

"I prefer to use WhatsApp for online teaching and learning. It is easy to use and nowadays all parents who own smartphones has WhatsApp application." (Teacher 2).

There are many factors influenced the students in choose their favorite E-learning media. The reasons for the choose the media are: (1) students enjoy the media because simple and easy to use, (2) the media is cheaper and save students quota than other, (3) the students are more enthusiastic and more active in learning process because the media better than other, (4) the students said that the media can support their distance learning, and (5) still can meet their friends and lecturers face to face even just in monitor.

From the finding and explanation above, the researchers can say that the use of e-learning media has influenced to the students' perception about learning process in pandemic era. This is indicated by 
students' perceptions of the use of E-learning at this time. The types of e-learning applications that favorite between students and lecturers are also different.

By following interviews with lecturers, it was concluded that E-learning is still unsuccessful in realworld situations. From the lecturers' perspective, the most significant challenges are a lack of institutional support, such as some institutions failing to provide resources for lecturers to conduct E-learning processes (no financial support to purchase internet data), and a lack of a specific online learning application provided by the institution, causing lecturers to mix applications such as WhatsApp group chat with Zoom, or WhatsApp group chat only, or Google Classroom only.

Moreover, because not all students can afford a high-speed internet data package, and other students do not have internet access at all in their remote locations, lecturers may use the low-data consumption learning application. Finally, it appears that some students are unmotivated to learn since they do not interact directly with their lecturers, who can motivate, guide, and provide clearer instructions, as they would in a traditional face-to-face classroom.

Despite having time to adapt to online teaching and learning, and at the same time adhering to government initiatives to shift from the traditional classroom teaching to e-learning, teachers still have to ensure that learning can take place. There were various methods to utilize online teaching such as lectures, game based, task-based, problem-based learning projects, and discussion. In this study, 13 teachers gave worksheets to their students through WhatsApp, and the others mentioned project-based, inquiry-based, online quizzes, and educational videos.

"I find it easier to send worksheet or task through WhatsApp, parents easily can understand my instruction and let students complete the worksheet given. Plus, I can easily send any related materials(notes) I find in the Internet for the English lesson." (Teacher 14).

"Giving worksheets is the best online teaching I can do for my students. I list out the learning steps in a simple language and attach the worksheet. Giving them time and ask them to send the pictures of their work through WhatsApp." (Teacher 15)

"I implement my online teaching sometimes using online quizzes. The quizzes are related to their learning, and through its students become more active and attracted to the learning." (Teacher 5)

Some of them also mentioned that they used various methods to reach to their students including giving worksheets through WhatsApp, and sending pictures or videos as extra support materials.

\section{Conclusion}

E-learning provides participants with an engaging learning experience. Learners can understand English in a variety of ways, including listening, speaking, reading, and writing in real-life circumstances. Students have a completely different learning experience than in traditional classes. Their access to information has likewise increased dramatically. E-learning provides learners with engaging learning opportunities. Unfortunately, in the midst of this global pandemic, this online platform for virtual learning is still not functioning properly; students and teachers are experiencing technical difficulties with internet access, either because the internet service is slow or because students can't afford to make video calls on programs like Zoom because they consume more internet data.

Finally for the conclusion, amid this COVID-19 pandemic, E-learning appears to be the only platform for teaching and learning. However, technology cannot take the place of actual classroom interactions in traditional schools. In education, the affective domain (attitudes) is also an important part that must be supported in order for learning to be successful. In traditional classes, teachers can readily monitor and influence students' attitudes and motivation. The cognitive and psychomotor domains of 
schooling should be developed in tandem with the affective domains. E-learning must keep evolving as a kind of interactive, creative, and unique learning to supplement traditional classroom meetings. Finally, the utilization of technology and information in E-learning should enable students to become more competitive students who can compete in the globalization period, as well as active, creative, and morally sound individuals.

\section{References}

Ghirardini, B. (2011). Food and agriculture organization of United Nations. E-learning methodologies. $A$ guide for designing and developing E-learning courses: A handbook. Italy: FAO (noncommercial use).

Stern, J. (2018). Introduction to online teaching and learning. International Journal of Science Education, $3,1-10$.

Vonderwell, S. (2004). Online learning: student role and readiness. Turkish Online Journal of Educational Technology, 3(3), 38-42. 